\title{
POVERTY IN NINETEENTH-CENTURY YORUBALAND
}

\section{BY JOHN ILIFFE}

ONE enduring belief about sub-Saharan Africa is that it had no problem of poverty until Europeans disturbed its pristine order. There were no poor, it is said, because land was freely available and the 'extended family' provided for even its most unfortunate members. This belief has made strange bedfellows. President Nyerere has stated it passionately:

Both the 'rich' and the 'poor' individual were completely secure in African society. Natural catastrophe brought famine, but it brought famine to everybody 'poor' or 'rich'. Nobody starved, either of food or of human dignity, because he lacked personal wealth; he could depend on the wealth possessed by the community of which he was a member. That was socialism.'

The same belief has been traditional among white South Africans:

The poverty of individuals which occurs among Europeans is not common among Natives. Their communal system cares for all its people. Broadly speaking there is no starvation because each man will share his food with others. This is the explanation of so very little having been needed from public funds in the way of poor relief for Natives. ${ }^{2}$

More recently, Jack Goody has made a similar belief part (although it is not an essential part) of his argument that the main contrast between pre-colonial societies in sub-Saharan Africa and those of Europe and Asia was that Africa generally lacked stratified classes with distinct subcultures, because it lacked intensive agriculture, literacy, and world religions but possessed exogamous polygyny and ample land. ${ }^{3}$ In this view, only those exceptional areas which did have intensive agriculture, literacy, and world religions - notably Ethiopia and, to a limited extent, the Central Sudan - possessed wealthy classes with distinct or emergent subcultures. ${ }^{4}$ By implication, only they had categories of poor people, for 'poverty... implies the opposite, riches, in the same way that slavery implies freedom' .5 Where categories of rich and poor were absent, so were religious charity, asceticism as an ideal, ${ }^{6}$ and, by implication, systematic begging. In the traditional three stages of care for the poor - family care, religious charity, and state responsibility - most of sub-Saharan Africa,

' Julius K. Nyerere, 'Ujamaa - the basis of African Socialism' (1962), in his Freedom and Unity (Dar es Salaam, 1966), 164.

2 Union of South Africa, Report of Native Economic Commission 1930-1932, U.G. 22, 1932 (Pretoria, 1932), 142.

3 Jack Goody, Cooking, Cuisine and Class (Cambridge, 1982), passim, esp. vii, 98-9, 206-7.

Ibid. 2 10-12, 193-4.

s Ibid. 194. This is at best a partial truth. It assumes that poverty must be defined in relative terms, but in poor countries there are strong arguments for defining it in absolute terms: see Amartya Sen, Poverty and Famines (revised edition, Oxford, 1982), ch. 2. Moreover, the two definitions are not mutually exclusive and neither is of any use to a historian of Africa because the data available are not good enough to test them. The only usable definition of poverty in Africa before the mid twentieth-century is a behavioural definition: the poor were those observed by others to behave as poor people behave.

- Goody, Cooking, 65, 191. 
so it is claimed, remained at the first stage of family care; only exceptional areas like Ethiopia and Hausaland had progressed to the second stage of religious charity.

The purpose of this paper is to challenge and, if possible, destroy this myth in order to open the way to serious historical study of poverty in Africa. Nineteenth-century Yorubaland is used as a test case for two reasons. One is that it was not only famous for strength of family organization but was arguably the most developed society in sub-Saharan Africa that had not yet adopted literacy, world religions, or intensive agriculture to any significant extent. If Yorubaland had no poor, then the chances of finding them elsewhere would be slim. The second reason for choosing Yorubaland is that the missionaries and evangelists (many of them Africans) who lived there during the second half of the nineteenth century wrote letters and often kept daily journals in which they recorded chance encounters with people of all kinds. These letters and journals are the main sources for this paper. ${ }^{7}$ Three caveats should be stated. First, Yorubaland's high level of urbanization admittedly made it untypical of sub-Saharan Africa, but there is no reason to think that towns are a necessary condition for the existence of poverty, although they do attract the poor and make them visible. Second, a total reliance on mission sources risks grave distortions which are familiar to historians of Africa. Third, the evidence from mission journals is not good enough to permit a sophisticated definition of poverty in terms of datum lines or life-styles relative to those of the wider society. The Yoruba poor were those who were described as needing help in order to survive. ${ }^{8}$

The first problem is to find out who the poor were. The mission journals and letters for the period I 845-1900 mention exactly 100 identifiable individuals who can be classified as poor. ${ }^{9}$ The number is obviously very small, although the sources also allude to other persons in similar circumstances without giving the details needed to identify the roots of poverty. The 100 individuals were probably especially impoverished, if only because they were noticed. They fell into four broad categories.

Thirty-five were elderly people: seventeen men and eighteen women. Of the men, the great majority were incapacitated: three were dying, seven were sick, three were blind, and one of the blind was also deaf. Characteristically they either had no relatives or had been abandoned by them: men like the 'dry bone' who took refuge with a missionary in Ijaye and died 'unknown, without the sorrow of any relative' in $1858 .{ }^{10}$ Such aged, sick, and im-

The main sources are the records of the Church Missionary Society [CMS] in Birmingham University Library. There is no material relevant to this subject in the records of the Wesleyan Methodist Missionary Society, which are in the library of the School of Oriental and African Studies, London. I am indebted to the librarians of both institutions. I am also grateful to the Executive Director of the Historical Commission of the Southern Baptist Convention for a microfilm of the papers of T. J. Bowen, although they do not contain data on poverty. I have not consulted other Southern Baptist or Roman Catholic records. Dr Jeremy Eades and Dr John Lonsdale have made valuable comments on drafts of the paper, although I have not always been able to incorporate them.

${ }^{8}$ See above, note 5 .

- I have included material on Badagry because, although not strictly a Yoruba town, it was part of the same mission field and was culturally very closely related. Little material on Lagos is included because its records, which are distinct and very extensive, would need a separate study. Most material is from Abeokuta and Ibadan.

10 Mann, journal, 30 October I858, CMS C.A2/O.66/95. 
poverished men generally withdrew from towns to outlying farm villages where food was cheaper and easier to find, but life 'in farm' bred loneliness and neglect, so that they were often anxious to be carried back to town when they felt their end approaching. Although only a minority seem to have been strangers to the towns where the mission staff met them, the strangers often suffered especially severely. ${ }^{11}$ The aged women differed from the men in that only a minority were incapacitated: five were dying, two were sick, and one was blind. What generally marked out the remainder was that they were widows without attendant relatives. Mature Yoruba women enjoyed much economic independence and were often responsible for bringing up their children. ${ }^{12}$ In old age they were consequently especially dependent on their children - a remarkable number of elderly Yoruba women followed their sons in becoming Christians - so that lack of children or neglect by them could breed great misery. When one elderly Christian died an evangelist wrote, 'She having no child to take care of her in bed of illness, had been earnestly praying that God should not visit her with any lingering illness'. ${ }^{13}$ As with aged men, strangers and refugees were especially liable to neglect. An African clergyman mentioned

an old Ijaye woman, who, on the destruction of her native town by war, drifted about from place to place till at last, she came to Otta. Here nobody would receive her into his house and she was obliged to seek shelter under a tree where she lay awaiting her end. Naked and almost-starved-to-death, there was scarcely any thing left of her but skin, bone, and respiration. ${ }^{14}$

The largest category of the poor -42 of the 100, equally divided between males and females - are mentioned in the mission records either as adults or without any indication of age. Silence on that point probably indicates adulthood, a supposition supported by the fact that 35 of the 42 were incapacitated : 4 were dying, 2 I were sick, 9 were blind, and 4 were insane. ${ }^{15}$ Among mature Yoruba, it appears, the main cause of poverty was incapacitation, and that was a basic feature of poverty in this society. Probably the most common incapacitating disease among adults was Guinea worm; it could immobilize whole households and villages, cause intense pain, and occasionally prove fatal, ${ }^{16}$ but generally it bred only temporary poverty. Leprosy was less common but much dreaded:

The widow of late Andrew Ajaye... died a few weeks ago; she had been a leper for 15 years... When she died the Christians would not bury her and would not allow her being interred into our graveyard as no grave could be dug there in the future... She was accordingly buried outside the town by the lepers. ${ }^{17}$

11 For a typical case see W. S. Allen, journal, 11 September 1882, CMS $\mathrm{G}_{3} / \mathrm{A}_{2} / \mathrm{O} / \mathbf{1 8 8 4} / \mathrm{r} 0_{3}$.

${ }_{12}$ See N. A. Fadipe, The Sociology of the Yoruba (Ibadan, 1970), chs. 4 and 5 .

13 Doherty to Long, 17 May 1882 , CMS G3/A2/O/1882/1 12 .

14 White to Venn, 6 June 1867, CMS C.A2/O.87/23.

16 Three were incapacitated in more than one way.

10 Oyebode, journal, 23 July $1890, \mathrm{CMS} \mathrm{G}_{3} / \mathrm{A}_{2} / \mathrm{O} / \mathrm{1} 89 \mathrm{r} / 123 ; \mathrm{W}$. Allen, journal, 16 November 1876, CMS C.A2/O.18/26; Olubi, journal, 25 November 1883, CMS $\mathrm{G}_{3} / \mathrm{A}_{2} / \mathrm{O} / 1884 / 100$.

17 Maser to Venn, 28 June 1867 , CMS C.A2/O.68/76. By 1910 missionaries had founded two leprosaria in Abeokuta: see A. K. Ajisafe, History of Abeokuta (second edition, Bungay, 1924), 180; Tugwell to Baylis, 6 May $1895, \mathrm{CMS} \mathrm{G}_{3} / \mathrm{A}_{2} / \mathrm{O} / 1895 / 90$. 
With regard to insanity, Yoruba recognized several varieties and adjusted their behaviour to them: those who took life were killed, the violent were fettered and sometimes flogged, while the harmless were sent to live with an indigenous specialist or allowed to wander freely, sometimes at the risk of maltreatment. ${ }^{18}$ As usual, the greatest misery was suffered by strangers and unwanted slaves, ${ }^{19}$ but there were cases of extreme poverty among women with small children who had been abandoned by their husbands. ${ }^{20}$

Ten children and adolescents formed the third category of poor. Seven were sick, which suggests that children, like adults, were mainly reduced to poverty by incapacitation. As a proportion of the total they were far fewer than was normal in pre-industrial Europe. ${ }^{21}$ In this respect, family structure, the availability of land, and the universal love of children probably did provide for many who in other cultures would have become paupers. Yet not all orphans could be sure of acceptance by their relatives. Disease was one obstacle:

Today I had to bury a heathen boy of 7 or 8 years old. He had lost by death his parents nearly two years. Since then he was destitute of every thing but hard and rough usages by his relatives. He had nothing like what one might call care - but ugly, dirty looking boy. No clothe hardly on his back, no cap, or trousers to wear no food hardly - proper or improper; and for a year he never had any washing. Living under these disastrous circumstances he had incured the incurable disease of drowsiness, ${ }^{22}$ for which he was cast out. Once this boy came to my house sick, naked, and starved looking creature and begged for admittance. I went out to inquire to which house he belongs. His relative came during my absence and whipped him out. He was sent to farm and there chained for several days. And no sooner he was released, then he came to me much worse than before - actually he was dying. I then determined to keep him. ${ }^{23}$

The other main reason why relatives might reject an orphan was that she was blamed for her parents' deaths. In I 863 an African clergyman in Otta found a little girl begging for cowrie shells. She had yaws and her feet were so disfigured that she could walk only on her heels. She was an orphan from Lagos. A man in Otta had cast her out, 'saying that she is a witch and that having killed her father and mother, she would kill him, for in this country, a child who has unfortunately lost father and mother is supposed to be possessed of the witchcraft and is frequently reproached for killing the parents. ${ }^{24}$ At Ode Ondo in 1879 an orphan girl of twelve or thirteen, suffering from dysentery, was rejected by her relatives and her intended husband on the grounds that she had eaten some forbidden food, although she denied it. ${ }^{25}$

18 W. S. Allen, journal, 9 November $1888\left(\mathrm{CMS} \mathrm{G}_{3} / \mathrm{A}_{2} / \mathrm{O} / \mathrm{I} 889 / 129\right)$ and $22 \mathrm{May}$ I 882 (CMS G $3 / \mathrm{A2}_{2} / \mathrm{O} / 1884 / 103$ ); J. Okuseinde, journal, 17 November 1882 , CMS $\mathrm{G}_{3} / \mathrm{A}_{2} / \mathrm{O} / \mathrm{1} 88_{4} / \mathrm{IO2}$; T. King, journal, I6 May 1855, CMS C.A2/O.61/56; George, journal, 27 May 1873 , CMS C.A2/O.4I/6.

10 E.g. Gollmer, journal, 15 October 1851 , CMS C.A2/O.43/113.

${ }^{20}$ E.g. Cole, journal, 13 September 1871 , CMS C.A2/O.29/8.

21 See Olwen H. Hufton, The Poor of Eighteenth-century France, $1750-1789$ (Oxford, 1974), 12, 108.

22 A large proportion of the sleeping sickness cases mentioned in the mission records were children or young people.

23 Olubi, journal, 2 June 1868 , CMS C.A2/O.75/21 .

24 White, journal, 17 February $186_{3}$, CMS C.A2/O.87/65.

${ }^{26}$ Young, journal, 2 February and 6 March 1879, CMS C.A2/O.98/24. 
The last category of identifiable poor consisted of thirteen infants, not one of whom is mentioned as being sick. Most were foundlings abandoned at the deaths of their mothers, several of whom were slaves. Daniel Olubi, the Anglican pastor in Ibadan, described a typical case in 1880 :

I visited a heathen neighbour on the death of a slave woman. In the course of conversation I learnt that the late woman's child, six months old, was thrown away five days ago. A little boy took us to the bush: standing afar off, he pointed his finger toward the place where the poor child was cast. We made a search and the child was soon discovered. ${ }^{20}$

Not all foundlings had slave mothers: the future Bishop of Ibadan, A. B. Akinyele, was left to die on a dung-heap when gravely ill, lest he infect the rest of the family. ${ }^{27}$ Nor, of course, did families always reject orphaned children. That accounts of grandmothers or other relatives taking care of them are quite rare is probably because they were too normal to be recorded. Nevertheless, a substantial number of foundlings came into the care of missionaries. J. B. Wood, the veteran missionary at Abeokuta, wrote whilst on leave in 1893 :

While Mrs. Wood and I were out last term some twenty babies were brought to us whose mothers had died, and who in consequence were in dire need. About half of them we accepted the care of at our own expense; the rest we were reluctantly compelled to refuse to receive. This was in addition to several which were taken by the Misses Tynan and Wright. Such babies are generally in a very weakly state when brought, arising from various causes, but mostly from the ill health and weakness of their deceased mothers and the lack of such intelligent care as in such circumstances they need. Natives have a superstitious fear of such children, and will have nothing more to do with them than they can help, and so they are commonly exposed and die. ${ }^{28}$

In a later letter Wood added:

I doubt much if the 'babies' would be taken into such [Christian] families at all. It is a pity that it is so, but it is the fact that too many Christians are under the prevalent heathenish superstition that 'babies' whose mothers have died are dangerous and to be avoided. There are those who are more or less free from this wrong idea, but I fear their number is not large, and it would only be in certain circumstances that any of these could if they would take a baby...

It would be less difficult to place out children than babies in Christian families. What degree of readiness there would be to take them I cannot say. If it were profitable for those who took them there would, I dare say, not be much difficulty in placing them out...

It should certainly be taken for granted that children placed out with Christian families would have to be paid for. ${ }^{29}$

Most Christians at this time came from the poorer strata of Yoruba society. Their greater willingness to foster children rather than infants followed from the realistic view which Yoruba and other poor peoples had to take of the

${ }^{26}$ Olubi, journal, I November $1880, \mathrm{CMS} \mathrm{G}_{3} / \mathrm{A2}_{2} / \mathrm{O} / \mathrm{188}$ I/99. For a detailed account of a similar case, see Seventeen Years in the Yoruba Country: Memorials of Anna Hinderer (London, 1872), 104-6.

27 T. A. Adebiyi, The Beloved Bishop: the Life of Bishop A. B. Akinyele (Ibadan, 1969), 27-8

${ }^{28}$ Wood to Baylis, 2 August $1893, \mathrm{CMS} \mathrm{G}_{3} / \mathrm{A}_{2} / \mathrm{O} / 1893 / 116$.

20 Wood to Baylis, 8 January $1894, \mathrm{CMS} \mathrm{G}_{3} / \mathrm{A}_{2} / \mathrm{O} / 1894 / 4$. 
expense of caring for unproductive infants and the need for even young children to contribute to family income. ${ }^{30}$

The abandonment of unwanted infants has been common in pre-industrial societies. In late eighteenth-century France some 40,000 were abandoned each year, the number varying with grain prices. ${ }^{31}$ Abandoned children in Europe were a symptom of conjunctural poverty, which reduced healthy adults and their children to destitution at times of bad weather, dearth, unemployment, or disorder, whereas structural poverty embraced chiefly the aged and infirm. Conjunctural poverty especially affected adults with young families. ${ }^{32}$ That Yoruba understood the nature of family poverty is shown by an Ifa divination verse:

The poverty of a bachelor has no head [i.e. cannot be explained]

But that of a parent is slightly better. ${ }^{33}$

Yet most poverty in nineteenth-century Yorubaland was structural: it affected the old, the sick and orphans. It was less often family poverty than the result of a lack of family, or at least of relatives willing to undertake their responsibilities. Many sources of conjunctural poverty in Europe did not afflict Yorubaland. The weather was scarcely a problem. Famine, the main cause of conjunctural poverty in pre-colonial Africa, visited Yorubaland only rarely and in a localized form during the second half of the nineteenth century. Unemployment seems to have affected only Lagos, whose poor occasionally 'betake themselves to the farms or some other places, where they can earn a quiet living', ${ }^{34}$ but they did so not because of the business cycle but when civil wars in the interior damaged trade. These wars were the one major source of conjunctural poverty. In 1880 , during the Kiriji War, Olubi reported from Ibadan that owing to the want of cowrie shells, 'many poor souls have been buried purely by starvation'. ${ }^{35}$ Six years earlier numbers of newly captured slaves from Ado had died in the streets of Ibadan from smallpox and starvation, 'for food is dear as well as cowries'.36 Dahomian raids on western Yoruba towns brought thousands of refugees streaming into Abeokuta. ${ }^{37}$ As always, the refugees were the weak. When Ibadan destroyed Ilesha in 1870, 'all the strong men of the Ijesa warriors are escaped but young and old women, children, and sick people of both sexes fall into their hands' ${ }^{38}$ The most dreadful scenes accompanied the siege and capture of Ijaye in I 860-2. 'Old people men and women and young children were being carried to the river Ose to die,' it was reported, 'whilst many

${ }^{30}$ For Yoruba attitudes on this point see 'A journal of Mr D. Coker, a catechist at Ido', n.d. [1872 ?] CMS C.A2/O.28/4; Donald Faulkner, Social Welfare and '̧uvenile Delinquency in Lagos, Nigeria (London, n.d.), 5.

31 Hufton, Poor, 318; Claude Delasselle, 'Les enfants abandonnés à Paris au XVIIle siècle', Annales, E.S.C. xxx (1975), 207-8; Mikiso Hane, Peasants, Rebels, and Outcastes : the Underside of Modern fapan (New York, 1982), 209-10.

${ }^{32}$ See Jean-Pierre Gutton, La société et les pauvres en Europe (XVIe-XVIIIe siècles) (Paris, 1974), 72-3; Hufton, Poor, 12, 20; Gareth Stedman Jones, Outcast London (Oxford, 1971), 44, 5 I.

3s 'Wande Abimbola, Ifa: an exposition of Ifa literary corpus (Ibadan, 1976), 108.

$34 \mathrm{~N}$. Johnson to ?, 3 January 1879 , CMS C.A2/O.57/10.

ss Olubi to Fenn, 19 February 1880 , CMS C.A2/O.75/47.

${ }^{36} \mathrm{~J}$. Okuseinde, journal, 2 April I874, CMS C.A2/O.74/1 2.

${ }^{37}$ E.g. Wood to Lang, 6 August $1890, \mathrm{CMS} \mathrm{G}_{3} / \mathrm{A}_{2} / \mathrm{O} / 1890 / 117$.

${ }^{38}$ Olubi, journal, 8 June 1870, CMS C.A2/O.75/25. 
others were left to perish in the streets etc. there being no food for them, that many in order to obtain the means for subsistence put themselves and children in pawn and others even sold their relatives to procure food to eat. ${ }^{30}$ A Baptist missionary took responsibility for some fifty children and evacuated them to Abeokuta. ${ }^{40} \mathrm{His}$ Anglican counterpart was caring for twenty in October 1861: 'Some the parents trusted to my hands for an advance of support, some I redeemed from those who had caught them, some I picked up in the streets, some dying parents begged me to take charge off. " 41 The average age of these children was seven.

Thus fragmentary sources permit a tentative identification of the poor of nineteenth-century Yorubaland. They were the most unfortunate among the old and among the sick adults and children, especially those without family support, plus orphaned infants and the victims (often children) of civil war. To these might be added two other categories: those at least temporarily impoverished by debt, who were often forced to pawn themselves or their dependants; ${ }^{42}$ and the inhabitants of certain isolated towns and villages who were either preyed upon by stronger groups or felt themselves impoverished by comparison with larger towns. ${ }^{43}$

On the other hand, it is worth noting who the poor were not. Only ten of the one hundred identifiable individuals (seven males and three females) are described as slaves, although some orphan children of slave mothers should be added. Slavery may well have absorbed many who might otherwise have been paupers. There are reported cases of masters caring devotedly for sick or dying slaves, while the authorities occasionally threatened especially cruel masters, and the Yoruba generally (like slave-owners everywhere) prided themselves on their treatment of slaves. ${ }^{44}$ Yet many masters also feared their slaves. Some slaves rebelled against the authorities or individual masters. Others mutilated or even killed themselves rather than accept indignity or cruelty. ${ }^{45}$ Many of the worst cases of maltreatment in the records concerned slaves, so that James Johnson (a dedicated opponent of slavery) may have been right to stress their vulnerability:

All able bodied slaves have some care, but the sickly and the infirm have little or none and may sometimes be found dying neglected on the streets from starvation

39 'Report of the Ijaye Relief Committee', I October 1861, CMS C.A2/O.11/25. See also R. H. Stone, In Afric's Forest and Jungle, or Six Years among the Yorubans (Edinburgh, 1900), 184-8.

40 Harrison to Secretaries, 2 I October 1863 , CMS C.A2/O.45/39. See also W. O. Ajayi, 'A history of the Yoruba mission, 1843-1880' (M.A. thesis, Bristol University, 1959), 174.

1 Mann to Secretaries, n.d. [December 1865 ] CMS C.A2/O.66/34.

12 See esp. Crowther to Hutchinson, 10 September 1856, CMS C.A2/O.31/78.

43 E.g. anonymous journal, 26 April I 872, CMS C.A2/O.29/9; Doherty, journal, 5 and 6 May 1876 , CMS C.A2/O.35/11. The evidence does not permit investigation of social differentiation within villages.

44 Lijadu, journal, i I May I895, CMS G3/A2/O/1895/ı49; W. S. Allen, journal, 8 October 1877 , CMS C.A2/O.19/17; W. Allen to Wright, 19 November 1879, CMS C.A2/O.18/9. The most comprehensive account is E. Adeniyi Oroge, 'The institution of slavery in Yorubaland with particular reference to the nineteenth century' ( $\mathrm{Ph} . \mathrm{D}$. thesis, Birmingham University, 1971).

45 Olubi, journal, 22 January I 877, CMS C.A2/O.75/35; Wood to Lang, 14 July 1885 , CMS G3/A2/O/1885/133; S. Johnson, journal, 30 June 1874, CMS C.A2/O.58/2; W. S. Allen, journal, 7 February 1883 (CMS G $3 / \mathrm{A}_{2} / \mathrm{O} / 1884 / 103$ ) and 18 August 1892 (CMS G3/A2/O/1893/66). 
and disease, passers by or those about whose doors they lie dying, and women amongst them, manifesting stolid indifference and unconcern... . Slave babies may sometimes be found by the side of their dead mothers thrown out on the muddy bank of some river. ${ }^{46}$

The poor were not especially concentrated in any one town; 35 were reported from Abeokuta and 34 from Ibadan, but this simply paralleled the location of missionary work. Nor is there evidence that certain Yoruba were poor because other Yoruba were rich. Formulated in this way, Goody's observation might be correct. There may also have been no distinct subculture of poverty, although Richard Lander, the most plebeian of early European travellers in Yorubaland, described the poor of Oyo as markedly underprivileged in food and dress, and there is other scattered evidence on this point. ${ }^{47}$ Certainly there was no observable grouping of the poor, no underworld, and no collective action. The poor Yoruba was strictly an individual; that was partly why he was poor. Yet there was nothing unfamiliar or alien about poverty. Both Crowther's vocabulary of 1852 and Bowen's dictionary of 1858 have words of Yoruba origin for a poor person (osise, otosi, oluponju), destitution (aini), and charity (ifeni, ore anu), as well as the Hausa (ultimately Arabic) loan-word talaka for a poor man. ${ }^{48}$

In all cultures the most striking characteristic of the poor is their ingenuity in finding ways to keep alive. ${ }^{49}$ Probably one distinctive feature of poverty in Yorubaland was the ease with which the poor could find means of survival, for Yoruba 'agrotowns' combined access to land with a high measure of occupational specialization which gave scope for the ancillary services on which many poor commonly depend. Just as elderly men cultivated the land to the last moment of their physical capacity, so elderly women took their place in the market, where pinches of salt were sold as delicacies and a woman trading in food might need a capital of less than $2 s .6 d$. (at 1930 s values). ${ }^{50}$ The habit of buying much ready-cooked food provided both nourishment for single men and occupations for women. Moreover, since 'almost every female child is trained to sell from a very early age', 51 it was logical that only those orphaned girls who were sick or otherwise afflicted were rejected. Many thousands of people found casual employment as porters. 'Perhaps the lowest [paid] work done here', a clergyman wrote from Otta in 1855 , 'is that of carrying the loads of the traders from Ota to Lagos and Agbaje which is chiefly done by women and girls and the pay is from 8 to 25 strings a day in

46 'Report from Revd. J. Johnson', August 1877 , CMS C.A2/O.56/50.

47 Richard Lander, Records of Captain Clapperton's Last Expedition to Africa (London, 1830, second edition, 1967), II, 205, 208, 21 3, 219 ; Richard and John Lander, Fournal of an Expedition to Explore the Course and Termination of the Niger (London, 1832), I, 188; T. J. Bowen, Adventures and Missionary Labours (second edition, London, 1968), 300; Stone, In Afric's Forest, 35.

48 Samuel Crowther, $A$ Vocabulary of the Yoruba Language (London, 1852); T. J. Bowen, Grammar and Dictionary of the Yoruba Language (Smithsonian contributions to knowledge, $x$ ) (Washington, D.C. ${ }_{2} 1858$ ).

40 The classic account is Henry Mayhew, London Labour and the London Poor (London, 185 I). See also Hufton, Poor, 367.

so John Whitford, Trading Life in Western and Central Africa (Liverpool, 1877 ; second edition, London, 1967), 101; Fadipe, Sociology, 156.

${ }^{81}$ Townsend to Venn, I May 1852, CMS C.A2/O.85/11. 
proportion as the loads are. ${ }^{52}$ This, of course, was a job for the able-bodied. So too, obviously, was war, which no doubt absorbed many homeless boys:

One of my boys who has been with me about 6 months, left me this morning: he said as he had now two cloths, and some cowries in hand he should go and join one of the Illorin war parties: but eventually went to join Ibadan, in one of their marauding excursions. I was sorry that the boy should do so, as he was a miserable looking fellow when he came to me. ${ }^{53}$

The more feeble found other occupations. Old men might practise basketwork. Spinning was especially a task for elderly women. Plaiting hair was a professional occupation. ${ }^{54}$ Perhaps the lowest in the hierarchy of jobs (as in Mayhew's London) was collecting scrap, which in Yorubaland meant especially firewood and leaves. Bowen described such occupations in the 1850s:

There is no legal or customary restraint as to the choice of occupations, except that it is not reputable for women to labor on the farms. In their favorite capacity of traders, however, they are constantly engaged in bringing the produce which they have purchased from the farms to the market. Many poor women also obtain a living by supplying the market with firewood, which they sometimes bring from a distance of six or eight miles. Others gather large leaves, which they sell by the basketful to the market women to be employed as wrapping paper. ${ }^{55}$

Scrap merges easily into loot. The fires which ravaged Yoruba towns every dry season provided ample opportunities. In 1851 a missionary noticed in Badagry market 'a woman who had Idols to sell, that is old irons picked up from the burnt houses after the late war' ${ }^{56}$ Crime in its wider sense does not seem to have been a resource of the poor but rather of gangs and unemployed 'warboys' $; 57$ on this point, however, mission accounts are slender and unlikely to be reliable. The same might be doubly true of prostitution; the records do not mention it, save for the occasional individual harlot. ${ }^{58}$ Lagos had professional prostitutes in the $1880{ }^{58}{ }^{58}$ however, and the extent to which the poor took refuge in Lagos needs separate study.

There remains one major means of survival: begging. An important element in the myth that pristine Africa had no poor is the belief that beggars arrived only with Islam and Christianity. Parrinder wrote of Ibadan in $195^{\circ}$ that 'One social custom that Islam is introducing to southern Nigeria is that of begging. ${ }^{\text {'00 }}$ Bascom agreed: 'Beggars (alagbe)... have been known only since the appearance of the Hausa people of northern Nigeria in Yoruba

${ }^{62}$ White, journal, 3 May 1855 , CMS C.A2/O.87/47.

ss Meakin, journal, 25 April 1859 , CMS C.A2/O.69/1 2.

${ }^{34}$ Cross, journal, 14 September $188_{3}$, CMS G3/A2/O/s883/191; Cole, journal, II March 1873 , CMS C.A2/O.29/12; Sunday, journal, 4 January 1880 , CMS C.A2/O.84/1; Hinderer, Seventeen Years, 293.

${ }^{35}$ Bowen, Grammar, xviii. See also Williams to Maser, 24 November 1879, CMS C.A2/O.90/9.

${ }^{50}$ Huber, journal, 2 November 1851 , CMS C.A2/O.5IA/r.

${ }^{57} \mathrm{E}, \mathrm{g}$. J. Okuseinde, journal, 25 January ${ }_{1} 887, \mathrm{CMS} \mathrm{G}_{3} / \mathrm{A}_{2} / \mathrm{O} / \mathrm{1} 888 / 48$; Harding to Baylis, I August 1899, CMS G3/A2/O/1899/122.

${ }^{58} \mathrm{~S}$. Crowther, journal, 15 November I 852, CMS C.A2/O.32/56;S. Johnson, journal, 12 July $1881, C_{1 S ~ G} / A_{2} / \mathrm{O} / 1884 / 10$.

${ }_{50}$ Michael J. C. Echeruo, Victorian Lagos (London, 1977), 46.

${ }^{80}$ Geoffrey Parrinder, Religion in an African City (London, 1953), 75. 
territory ${ }^{\prime}{ }^{61}$ It is true that the expansion of Islam within nineteenth-century Yorubaland brought with it the exceptionally vigorous Hausa begging tradition. Europeans who visited the Islamic stronghold of Ilorin during the 1850 s noticed the difference:

A blind beggar by the way side asking alms in the name of the Prophet showed us we were in a country where another religion was professed [;] there are but few beggars among the heathen ... Ilorin ... is full of beggars... Mohammedan scholars, boys, are used to go about begging for their food, many came to us, frequently singing. We were constantly beset with people. ${ }^{62}$

Yet there are few references to Muslim beggars elsewhere in Yorubaland during the nineteenth century, except in Lagos, where beggars were by 1889 'an intolerable nuisance' to some observers. ${ }^{33}$ Elsewhere the earliest clear reference to a Muslim beggar comes from Ibadan in $1882 .{ }^{.64}$

Yet missionaries met many beggars, for the Yoruba had an indigenous tradition of begging which refutes all the stereotypes about the absence of poverty from pristine Africa. Both Crowther and Bowen, in the 1850 , list the word alagbe for a beggar, while Crowther also has another word, madekoso, for 'a beggar who goes from house to house to tell news, by which he gains his livelihood'. ${ }^{85}$ That, however, was not the alagbe's normal behaviour, which was rather an outgrowth of religious practices. Missionaries habitually called Yoruba beggars 'devil-mongers'. This was because they normally carried or sat next to a figurine of Eshu, ${ }^{68}$ who was the intermediary between Olorun (Owner of the Heavens) and men but was misinterpreted by missionaries as the devil. ${ }^{67}$ The beggar either offered the figurine for passers-by to touch, or called Eshu's blessings on them, or simply sat and waited for passers-by to place a cowrie shell or two beside the figurine. 'We met an Elesu woman (Devil Priestess) sitting under a tree in his street blessing the passers by, and receiving a cowry or two from different individuals', it was reported from Oyo. ${ }^{68}$ In Ibadan a harder-selling technique was practised:

Went on a visit this morning to the gateman and found there a man with an Idol cut out of wood, dyed with blue, the eyes were made of lead, and few cowries and beads were hanged about its body. It was superstitiously believed by them that this is (Esu) devil, he went there unporpose to get cowries from those going to trade in Abeokuta, and was saying whoever he bless it shall follow him, and whoever he curse it shall follow him, people were so frighten that they gave him enormous cowries. ${ }^{69}$

This begging tradition had probably grown from the custom by which

61 William R. Bascom, 'Social status, wealth and individual differences among the Yoruba', American Anthropologist, LIII (195 I), $49 \mathrm{I}$.

62 Townsend, journal, 16 and 21 August 1859 , CMS C.A2/O.85/265.

63 Fred I. A. Omu, Press and Politics in Nigeria, 1880-1937 (London, 1978), 106.

o4 J. Okuseinde, journal, 14 January $1882, \mathrm{CMS} \mathrm{G}_{3} / \mathrm{A}_{2} / \mathrm{O} / 188_{4} / 102$.

os Crowther, Vocabulary, s.v. Madekoso.

o6 There are excellent photographs of such figurines in Joan Westcott, 'The sculpture and myths of Eshu-Elegba, the Yoruba trickster', Africa, xxxII (1962), 336-54.

67 For Eshu and the other divinities mentioned here see E. Bolaji Idowu, Olodumare: God in Yoruba Belief (London, 1962).

${ }^{88}$ Akiele, journal, 25 January $1888, \mathrm{CMS} \mathrm{G}_{3} / \mathrm{Az}_{2} / \mathrm{O} / \mathrm{1} 889 / 130$. 'His' refers to Tela Kofoworola.

99 W. S. Allen, journal, 12 September 1867, CMS C.A2/O.19/5. 
priests and cult-groups demanded offerings from passers-by in honour of the particular divinity they worshipped, the offerings perhaps being understood as a gift exchange in return for divine favour. 'I met with an Obatala priest', an evangelist reported, 'who stood in the road near the market pronouncing blessing on any person he saw passing by him, that the Obatala will give them children, the Obatala will give them long life, and will give them plenty of cowries, these women always feel glad when receiving such blessings from the priest, and are always much delighted to give out a few cowries. ${ }^{\prime 70}$ The practice was not confined to priests, however, for almost every Yoruba was dedicated to some divinity and possessed its image. In 1855 an army set out from Ijaye:

Numberless images of different sorts were brought out to the gate of the town which the soldiers were passing, and along the public street which leads to Are's house. These were brought out by the females. The opportunity was embraced by the different image worshippers, for the purpose of getting cowries from the soldiers going out for their war expedition. The females got from each of the soldiers from 2 to 4 cowries. They got the cowries by praying for the soldiers in the name of the images. By these offerings of the soldiers, they expected propitious blessings from the images for preserving their lives as well as to catch many slaves. ${ }^{11}$

Figurines were used not only for begging but to attract blessings of all kinds. 'I often observe', a missionary wrote from Ibadan, 'that the heathen when sitting in the market have by their side their favourite idols, to give them good success in the disposal of the articles they expose for sale; that when they go from home they carry the same with them, sometimes on their heads and sometimes in their bosoms, to guard and protect them. ${ }^{72}$ Nor was it necessary for a beggar to make use of a figurine. A missionary in Ibadan passed 'a blind begging woman who did not get tired to sing all day long "He that is blessed imparts", , while an evangelist in Ogbomosho reported that 'an aged, and sickly Babalawo man [diviner] came to me this morning to beg for alms'. ${ }^{73}$ Nor did those beggars who used a representation necessarily use Eshu's:

We came across a woman in the street, sitting by the way side with her snake god, blessing every individual who might be passing, and receiving a cowry or two from them. We plainly assured her that the god Ogun was not the true God to worship... Before we left, the woman secretly confessed to us that all we have said is true, 'but there is no other means', she added, 'by which I can earn my livelihood'.74

Nevertheless, most beggars did carry a figurine of Eshu, perhaps because Eshu was the divinity who interfered most frequently in human lives, perhaps because he was especially associated with cowrie shells and markets. ${ }^{75}$ Some mission descriptions of 'devil-mongers' may in fact refer to Eshu's officers collecting market dues. Nevertheless, some 'devil-mongers' were truly destitute. Others were elderly people who appear to have made a modest living

${ }^{70}$ George, journal, 18 March 1874 , CMS C.A2/O.41/8.

71 C. Phillips, journal, 22 March 1885 , CMS C.A2/O.77/11.

72 J. Smith, journal, I January I 866, CMS C.A2/O.83/20.

73 Kefer, journal, i 3 May 1855 , CMS C.A2/O.59/9; Akiele, journal, 30 May 1892 , CMS $\mathrm{G}_{3} / \mathrm{A}_{2} / \mathrm{O} / 1893 / 18$.

${ }_{74}$ Akiele, journal, 1o September $1890, \mathrm{CMS} \mathrm{G}_{3} / \mathrm{A}_{2} / \mathrm{O} / \mathrm{1} 891 / 121$.

75 Westcott, 'Sculpture', 337-8, 345-6. 
by begging..$^{76}$ Scarcely any were children, in sharp contrast to the prevalence of child beggars both in Ilorin and in Europe. A few beggars were apparently healthy and prosperous men, 'sturdy beggars' in the fullest sense, just as professional musicians sang the praises of great men in hope of reward. ${ }^{77}$ 'Is it not better to beg than to rob?' asked a proverb. ${ }^{78}$ There is no evidence that ordinary Yoruba made any ethical distinction between deserving and undeserving poor, although the authorities could be more severe:

Today one of the candidates for baptism met up with some devilmongers in the streets, who came from a neighbouring town to beg for alms for the devilish fetishes which they were carrying about. They asked for alms from the woman in the name of the devil. She not only refused, but also tried to shew them from her own experience how unprofitable such offerings are, when the devilmongers raised a clamour against her, in which the idolatrous bystanders joined. The woman still maintained her ground and a controversy ensued. The approach of the Lisa [the town's dominant chief] soon caused a pause. When he (the Lisa) reached the spot, he halted, and after gazing on the devilmongers for sometime, he ordered that they should immediately leave the town. ${ }^{78}$

Begging in Yorubaland seems to have been an exploitation of religious practices by the poor, as it was in Christian and Islamic cultures. Yoruba beggars did not pretend to sell something, as did their contemporaries in London, because in Yorubaland there was no greater disgrace in begging than in being poor. Although, as in Ethiopia, beggars can proliferate without normally receiving currency, nevertheless its use in Yorubaland probably encouraged them.

Yorubaland had not only beggars but ascetics. Again the practice had religious roots. Olubi recorded in 1873

the death of my cousin Otunbaloku, one of the members of the Ake Church [at Abeokuta], who had been my high priest in the worship of the goddess Obatala in $1842 \ldots$ He had 72 disciples or followers of this god. He was also a great farmer by which he made himself a gentleman. But in process of time this Orisa forbad him from the lawful trade of farming for about 25 years, that he was obliged to carry about, long iron staff which was known to belong to this Orisa, the use of which was to carry about every five days as a day set apart for this Orisas worship. He went therefore with this long staff from street to street, house to house, dancing and blessing people. He received from individuals a cowry or two, but a generous giver may give 4 cowries for his arduous labour; and the result of a whole day route in this way amounts sometimes to 2 strings sometimes to 4 strings. ${ }^{80}$

Another mendicant devotee of Obatala visited the historian Samuel Johnson at Oyo. ${ }^{81}$ In the If a divination corpus there are verses which prohibit the client from farming ${ }^{82}$ and many of the mendicant priests described in the mission sources may have received a religious calling of this kind. An evangelist on Ido Island near Lagos wrote of the devotees of a divinity named Ara, 'They

76 Townsend, journal, 9 January 1852 , CMS C.A2/O.85/248.

77 Young, journal, 2-4 May 1878 , CMS C.A2/O.98/21 ; Hinderer, journal, 7 May 1853 , CMS C.A2/O.49/106.

${ }_{78}$ W. S. Allen, journal, 7 December $188_{3}, \mathrm{CMS} \mathrm{G}_{3} / \mathrm{A}_{2} / \mathrm{O} / 188_{4} / 103$.

72 C. Phillips Jr, journal, 27 December 1877 , CMS C.A2/O.78/r 9.

${ }^{80}$ Olubi, journal, 10 January 1873 , CMS C.A2/O.75/28.

81 S. Johnson, journal, 17 June $1887, C_{M S ~ G} / A_{2} / O / 1887 / 212$.

${ }_{82}$ William Bascom, Ifa divination (Bloomington, 1969), 87. 
are not to work but they live on the alms, in most cases extorted from the people'. ${ }^{83}$ The notion that religious experts should be poor was not foreign to the Yoruba. 'Formerly,' a diviner told a missionary in 1849 , 'the Ifa Priests were not to aspire after riches, nor permitted to have any slaves, and they were expected to be benevolent toward the poor ; but now they are greedy for gain, have slaves, and oppress the poor. '84 On the other hand, Yoruba ascetics lived in public; there is no indication of the eremitic type. 'Quiet seclusion is not among the values that a Yoruba recognizes', one of them wrote,$^{85}$ and the evangelists' journals are markedly less introspective than the missionaries'. Yet the attribution of religious virtue to physical suffering existed, chiefly in the practice of collective flagellation at religious ceremonies. At Ekun, a township between Ode Ondo and Ilesha, a minister described 'a festival day of the Ipetus, a large section of the community. These deluded people observed their festival in a selftorturing way. They parade the town in companies, and now and then halt in the streets to flog each other in an awful manner. ${ }^{86}$ The best-known rite of this kind was the annual festival of Ogiriyan (or Ogiyan) at Ibadan. 'At this great festival', Olubi wrote, 'men, women, and children are seen flogging one another by turns at certain stripes to please the goddess Ogiyan and to show that they are most devoted worshippers. Some have actually lost their lives in this. '87' In 1895 a similar pattern of thought caused the ruler of Ode Ondo to sit in the sun in the public street from noon till nightfall as 'a kind of penance' to drive smallpox from the town. ${ }^{88}$ That the prayers of the poor were especially acceptable to the gods seems to have been implicit in the whole pattern of begging. It was explicit in explanations of deformity, for the blind, deaf, dumb, lame, and other unfortunates were held to have been fashioned thus by Obatala and to be under his special protection. ${ }^{89}$

This evidence of ascetic ideas and practices is admittedly fragmentary but it must surely refute the notion that asceticism exists only in the company of intensive agriculture, literacy, world religions, and differentiated subcultures. Rather, in Yorubaland an indigenous ascetic tradition seems to have survived into Christianity. Among early Christians there, E. M. Lijadu forsook his mission salary to live as a self-supporting evangelist 'as naturally as possible among the people, to work with my own hands as they do, to eat what they eat, and to be content with little whilst helping the Church onwards to self support', although he saw this life-style as a revolt against Yoruba religious tradition. ${ }^{90}$ Mojola Agbebi was another early Christian ascetic who 'ate sparingly - usually a handful of parched corn or beans. He believed in occasional fasting as an aid to the speedy answer of prayer. He was a vegetarian in the Gandhian style, a total abstainer, a non-smoker and a

8s 'The report of David Ogusola Williams. Ido. January to December 1883', CMS $\mathrm{G}_{3} / \mathrm{A}_{2} / \mathrm{O} / 1884 / 69$.

${ }_{84}$ Church Missionary Record, 1850,77 . Abimbola, Ifa, I 7, notes the same tradition.

85 Fadipe, Sociology, 86.

${ }_{86} \mathrm{C}$. Phillips, journal, 24 February $1890, \mathrm{CMS} \mathrm{G}_{3} / \mathrm{A}_{2} / \mathrm{O} / 1890 / \mathrm{I} 66$.

${ }_{87}$ Olubi to Fenn, 28 December 1875 , CMS C.A2/O.75/43.

88 Lijadu, journal, 17 January $1895, \mathrm{CMS} \mathrm{G}_{3} / \mathrm{Az}_{2} / \mathrm{O} / \mathrm{1} 895 / 149$.

${ }^{80}$ Harding to Merensky, 18 October 1888 , CMS G3/A2/O/1888/172; William Bascom, Sixteen Cowries: Yoruba Divination from Africa to the New World (Bloomington, 1980), 37-8.

${ }^{90}$ Lijadu to Phillips, 13 January $1900, \mathrm{CMS} \mathrm{G}_{3} / \mathrm{A}_{2} / \mathrm{O} / 1900 / 52$. 
believer in the Judaic doctrine on pork.' 91 Isaac Akinyele, who became Olubadan of Ibadan in 1955, abstained from most physical pleasures, including sex, during the second half of his life. ${ }^{22}$ Elizabeth Isichei is surely right to see asceticism as one of the religious ideals linking Nigeria's indigenous, Christian, and Muslim religions - although only for a minority. ${ }^{93}$

The evidence on poverty in nineteenth-century Yorubaland is weakest on the subject of charity. This is partly because most of the charitable work mentioned in mission sources was naturally that of the missionaries and their congregations, who from an early date formed 'relief companies' or 'Dorcas societies' to help distressed Christians and, to a lesser extent, other destitutes. The society in Abeokuta existed by $1848 .{ }^{94}$ However, the lack of evidence on charity is also due to the lack of specialized charitable institutions in Yorubaland, for it has been from institutional records that the histories of charity and poverty in Europe have largely been written. The role of the authorities in caring for the poor in Yoruba towns is especially obscure. Crowther's vocabulary of 1852 quoted a proverb, 'A poor beggar never perishes from want in Oyo (the capital)', ${ }^{95}$ and Afolabi Ojo has stated that so many of the deformed took refuge at any royal palace that 'the Yoruba regarded it as a circus ', ${ }^{96}$ but the many descriptions of courts and palaces in the mission records do not mention concentrations of destitutes. Whatever public charity existed was most probably unsystematic: a divination verse describes a cripple who became rich through the chance favour of a king, ${ }^{2 ?}$ but the corpses of destitutes who died in Abeokuta were thrown on to a rubbish heap. ${ }^{98}$ Equally important and obscure is whether the many indigenous religious cults provided charity. These bodies were usually in part cults of affliction, in that some members were initiated into them as a way of curing sickness or relieving some misfortune. If it should prove that cults of affliction were among the most important institutions caring for the poor of pre-colonial Africa, this will call in question current notions that the transition from family responsibility to religious charity is particularly associated with world religions and literacy, and that African societies had not generally made that transition. For Yorubaland, however, there is at present no evidence to support this point, nor is there material on the charitable role of Islam, save passing references to almsgiving. Instead, accounts of individual acts of charity support the view that they were the function of kinsmen or wealthy patrons. Occasionally there was no personal relationship. The merchants of the coastal settlement at Leke were in 1875 collectively supporting an aged slave. ${ }^{99}$ Three years later Samuel Johnson recorded an impulsive gesture of humanity during one of Ibadan's dreadful fires:

11 E. A. Ayandele, $A$ Visionary of the African Church: Mojola Agbebi (1860-1917) (Nairobi, 1971), 22.

92 Ayokunnu Ogunranti, 'Pastor and politician: Isaac Akinyele, Olubadan of Ibadan (1862-1955)', in Elizabeth Isichei (ed.), Varieties of Christian Experience in Nigeria (London, 1982), 134.

93 Elizabeth Isichei, 'Introduction', in ibid. I-9.

${ }^{94}$ Müller, journal, I November 1848 , CMS C.A2/O.72/8.

${ }_{95}$ Crowther, Vocabulary, s.v. Alagbe.

96 G. J. Afolabi Ojo, Yoruba Palaces (London, 1966), 72.

97 Bascom, Sixteen Cowries, 392-9.

${ }^{98}$ T. King to ?, I April 1853 , CMS C.A2/O.61/2.

90 Young, journal, 22 January 1875 , CMS C.A2/O.98/9. 
I was touched by an act of generosity performed by a young warrior, the son of a great warchief. He was returning on horseback from the fire, when it became ungovernable, when he saw a man crawling on all four, as he could not walk from Guinea worm; and it was sure, he might have been burnt, as the fire might soon overtake him. He pitied the poor sufferer, dismounted, and lifted him upon his horse, walking after him.... What made me admire this in him is because it is inconsistent with a hardy soldier as he is, and the man is a stranger to him. ${ }^{100}$

More commonly, however, charity either required or created a personal relationship. Yoruba admired above all the gbajumo, the generous patron surrounded by many dependants. ${ }^{101}$ To refuse to accept a man as a pawn when he needed the money was considered uncharitable. Consequently most charity probably took place within the households of the rich. Many of the impoverished Christians of Ibadan had found refuge among the seventy or more people living in the compound of David Kukomi, whose benevolence and progeny dominated the Anglican church there. ${ }^{102}$ Apart from numerous family members, the household of William Moore, the wealthy Christian pastor in Oshielle, contained in 1880 at least five slaves, four pawns, and fifteen children supported by charitable funds from Europe. ${ }^{103}$ This pattern is likely to have been even more pronounced among great men who were not Christians. In respect of charity, the family-based compound probably did remain the key unit of Yoruba society.

This article has sought to do no more than demonstrate that poverty, begging, asceticism, charity, and their ancillary phenomena existed as important features of nineteenth-century Yoruba society and did not wait upon the adoption of world religions, literacy, or intensive agriculture. Whether that was true elsewhere in pre-colonial Africa can be shown only by research. These subjects have formed one of the richest fields of study in the social history of Europe and Asia. It is time that work began on them in Africa, where concern for the poor is not only of academic importance. But in order to begin this work we must first clear away the myth that pristine Africa had no poverty.

\section{SUMMARY}

It is widely believed that pre-colonial Africa south of the Sahara had no problem of poverty (and no beggars or ascetics) except in those few areas which already possessed intensive agriculture, literacy, world religions, and classes with stratified subcultures. This article uses the records of missionaries and evangelists living in nineteenth-century Yoruba towns to demonstrate the existence of paupers, beggars, ascetics and (with less certainty) charitable practices. It also considers the means by which the poor sought to survive. The article suggests that the absence of poverty from pre-colonial Africa is a myth and that the subject deserves full study.

100 S. Johnson, journal, 23 June 1878 , CMS C.A2/O.58/10.

101 P. C. Lloyd, Power and Independence : Urban Africans' Perception of Social Inequality (London, 1974), 51.

102 S. Johnson, journal, 7 July 1874 , CMS C.A2/O.58/3; Olubi, journal, 7 June 1875 , CMS C.A2/O.75/31; Adebiyi, Beloved Bishop, I1-18.

103 'Domestic slavery: minutes of a conference held at Lagos', 16-23 March I880, $\mathrm{CMS} \mathrm{G}_{3} / \mathrm{A}_{2} / \mathrm{O} / 1880 / 106$. 